Prepared in cooperation with the U.S. Environmental Protection Alyenty

The Riesponse of Suspended Sedjusenti, Jurbidity, and Velocity to listigrjes]

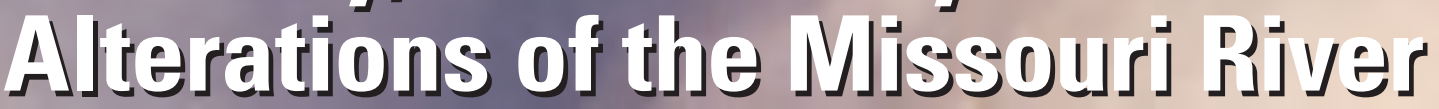

Circular 1301

1040 作,

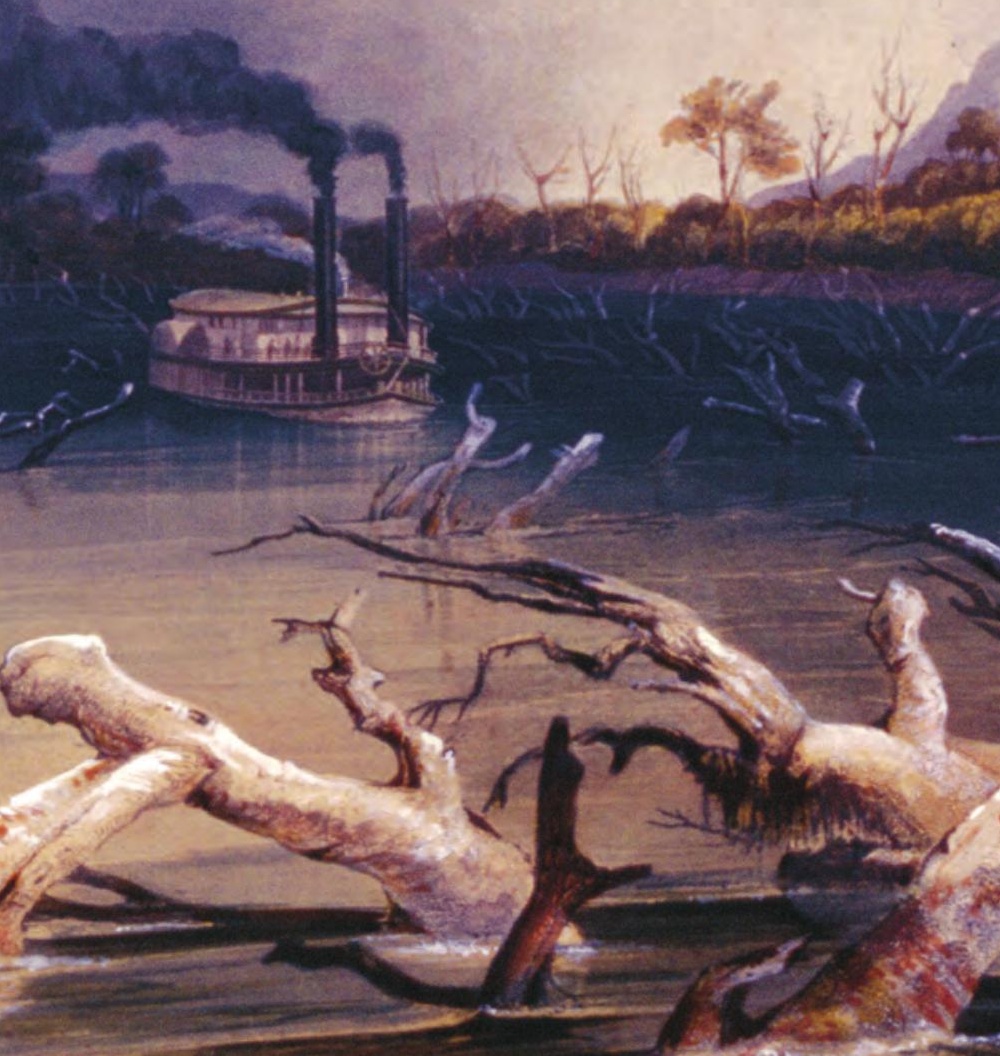

U.S. Department of the Interior U.S. Geological Survey 


\section{Timeline of Construction and Suspended Sediment and Turbidity Data Collection on the Missouri River}

\begin{tabular}{|c|c|}
\hline & CONSTRUCTION \\
\hline 1838-1929 & $\begin{array}{l}\text { Site specific bank stabilization and channel dredging projects completed. } \\
\text { Effects on suspended sediment and turbidity were minor. }\end{array}$ \\
\hline 1930-1936 & $\begin{array}{l}\text { Construction of } 6 \text { feet deep by } 200 \text { feet wide navigation channel with large-scale bank } \\
\text { stabilization. }\end{array}$ \\
\hline 1937 & Fort Peck Dam closed in Montana. \\
\hline 1950-1962 & $\begin{array}{l}\text { Construction of } 9 \text { feet deep by } 300 \text { feet wide navigation channel with large-scale bank } \\
\text { stabilization. }\end{array}$ \\
\hline 1952-1963 & Closure of five more large dams in North Dakota and South Dakota. \\
\hline & DATA COLLECTION \\
\hline 1804 & $\begin{array}{l}\text { William Clark observes approximately one-sixteenth of the volume of a Missouri River water sample is } \\
\text { suspended sediment. }\end{array}$ \\
\hline 1804 & Meriwether Lewis evaporates one pint of Missouri River water and gets 81 grains of evaporite. \\
\hline 1843 & $\begin{array}{l}\text { Edward Harris on the Audubon Expedition observes that about one-tenth of the volume of a Missouri River } \\
\text { water sample collected near present day Gavins Point Dam is suspended sediment. }\end{array}$ \\
\hline 1879 & $\begin{array}{l}\text { U.S. Army Corps of Engineers collect daily suspended-sediment samples from February } 1 \text { to October } 1 \\
\text { (Keown and others, 1981). }\end{array}$ \\
\hline 1900 & William Teichmann collects daily grab samples near St. Charles, Missouri, from January 24 to October 10. \\
\hline 1907 & $\begin{array}{l}\text { Richard Dole (U.S. Geological Survey) collects 10-day composite samples from October 4, 1906, to October } \\
\text { 14, 1907, at Omaha, Nebraska, and St. Charles, Missouri (Dole, 1909). }\end{array}$ \\
\hline 1929-1932 & $\begin{array}{l}\text { U.S. Army Corps of Engineers collects daily suspended-sediment samples from May 8, 1929, to July 22, 1932, } \\
\text { at eight sites on the Missouri River. Only monthly data were published (Chief of Engineers, 1935). }\end{array}$ \\
\hline 1973-2002 & $\begin{array}{l}\text { U.S. Geological Survey collects samples on approximately monthly intervals at Hermann, Missouri, and } \\
\text { Omaha, Nebraska. }\end{array}$ \\
\hline
\end{tabular}

Front Cover. Derived from Karl Bodmer's water color and pencil rendering of the unengineered Missouri River in 1833 near St. Joseph, Missouri (original used with permission from Josyln Art Museum, Omaha, Nebraska).

Back Cover. Left side, top: Log mat placed on top of graded bank to stabilize an outer bend of the Missouri River in Nebraska, 1934 (photograph courtesy of the U.S. Army Corps of Engineers).

Left side, middle: Lumber mattress constructed for bank stabilization on the Missouri River near Indian Cave Bend in Nebraska, 1937 (photograph courtesy of the U.S. Army Corps of Engineers).

Left side, bottom: Construction of rock wing dike on the Missouri River in Nebraska, 1934 (photograph courtesy of the U.S. Army Corps of Engineers).

Right side, inset: Typical rock wing dikes in modern Missouri River near Bonnott's Mill, Missouri (photograph from the U.S. Geological Survey). 


\section{The Response of Suspended Sediment, Turbidity, and Velocity to Historical Alterations of the Missouri River}

By Dale W. Blevins

Prepared in cooperation with the

U.S. Environmental Protection Agency

Circular 1301 


\section{U.S. Department of the Interior DIRK KEMPTHORNE, Secretary}

\section{U.S. Geological Survey \\ Mark D. Myers, Director}

\section{U.S. Geological Survey, Reston, Virginia: 2006}

For product and ordering information:

World Wide Web: http://www.usgs.gov/pubprod

Telephone: 1-888-ASK-USGS

For more information on the USGS-the Federal source for science about the Earth, its natural and living resources, natural hazards, and the environment:

World Wide Web: http://www.usgs.gov

Telephone: 1-888-ASK-USGS

Any use of trade, product, or firm names is for descriptive purposes only and does not imply endorsement by the U.S. Government.

Although this report is in the public domain, permission must be secured from the individual copyright owners to reproduce any copyrighted materials contained within this report.

Suggested citation:

Blevins, D.W., 2006, The response of suspended sediment, turbidity, and velocity to historical alterations of the Missouri River: U.S. Geological Survey Circular 1301, 8 p.

\section{Library of Congress Cataloging-in-Publication Data}

Blevins, Dale W.

The response of suspended sediment, turbidity, and velocity to historical alterations of the Missouri River / by Dale W. Blevins.

p. cm. -- (Circular ; 1301)

"Prepared in cooperation with the U.S. Environmental Protection Agency."

Includes bibliographical references.

1. Sediment transport--Missouri River. 2. River engineering--Environmental aspects--Missouri River Watershed. I. Title.

TC425.M7B583 2007

627 .1220978--dc22 


\section{Contents}

Historical Measurements ...........................................................................................................

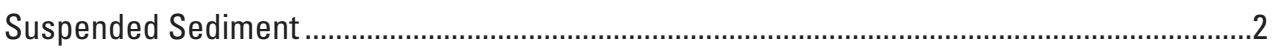

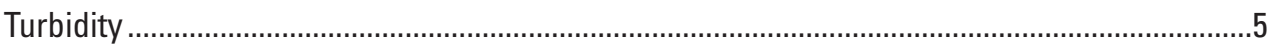

Comparison with Modern Measurements.................................................................................

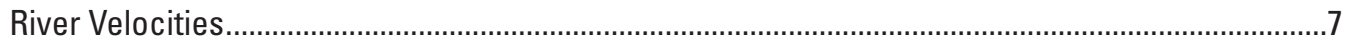

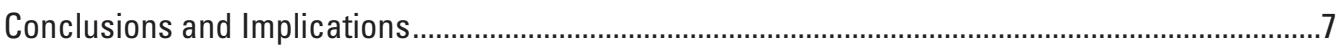

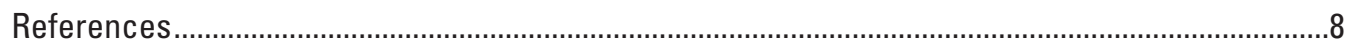

\section{Figures}

1. Map showing Missouri River Basin with location of historic and modern suspendedsediment, turbidity, and velocity sites on the Missouri River.

2-4. Boxplots showing:

2. Summary of suspended-sediment concentrations before dams, large-scale bank stabilization, and watershed development. 3

3. Summary of monthly suspended-sediment concentrations in the Missouri River ....4

4. Turbidity in 10-day composite of grab samples collected in the 1907 water year and turbidity in depth-integrated samples collected from 1973 through 2001

5-8. Graphs showing:

5. Turbidity with suspended-sediment concentration at Kansas City, Kansas, in the 1907 water year.

6. Average annual turbidity at the Kansas City, Kansas, Water Plant, 1918 through 1954 with best-fit fourth-order polynomial trend line

7. Relation between mean water velocity and discharge in the Missouri River at Waverly, Missouri, as recorded in U.S. Geological Survey discharge measurement notes

8. Relation between maximum water velocity and discharge in the Missouri River at Waverly, Missouri, as recorded in U.S. Geological Survey discharge measurement notes. 


\section{Conversion Factors and Datum}

\begin{tabular}{lcl}
\hline Multiply & By & To obtain \\
\hline & Length & \\
\hline $\begin{array}{l}\text { foot (ft) } \\
\text { mile (mi) }\end{array}$ & 0.3048 & meter $(\mathrm{m})$ \\
& 1.609 & kilometer $(\mathrm{km})$ \\
\hline & Volume & \\
\hline ounce, fluid (fl. oz) & 0.02957 & liter $(\mathrm{L})$ \\
pint (pt) & 0.4732 & liter $(\mathrm{L})$ \\
\hline & & \\
\hline foot per second (ft/s) & Flow rate & meter per second $(\mathrm{m} / \mathrm{s})$ \\
cubic foot per second $\left(\mathrm{ft}^{3} / \mathrm{s}\right)$ & 0.3048 & cubic meter per second $\left(\mathrm{m}^{3} / \mathrm{s}\right)$ \\
\end{tabular}

Water year: The 12-month period October 1 through September 30. The water year is designated by the calendar year in which it ends.

For suspended-sediment samples with concentrations less than 10,000 milligrams per liter, the density correction to convert to parts per million is less than 1 percent, which is less than the errors of sample collection and laboratory analysis. Therefore, analytical results in both units are comparable and no conversions of historical analyses from parts per million to milligrams per liter are necessary except for three large concentrations reported by William Clark, Meriwether Lewis, and Edward Harris, which are computed in milligrams per liter for comparison with modern measurements. 


\title{
The Response of Suspended Sediment, Turbidity, and Velocity to Historical Alterations of the Missouri River
}

\author{
By Dale W. Blevins
}

The heavy sediment load and large amounts of floating debris generated by the constantly caving banks of the Missouri River was documented in the first written description of the river by Father Jacques Marquette in 1673 as he approached the mouth of the Missouri River from the upper Mississippi River:

\begin{abstract}
"[We]" heard the noise of a rapid, into which we were about to run. I have seen nothing more dreadful. An accumulation of large and entire trees, branches, and floating islands, was issuing from the mouth of the river Pekitanoui (Missouri River), with such impetuosity that we could not without great danger risk passing through it. So great was its agitation that the water was so very muddy, and could not become clear."
\end{abstract}

However, large changes in suspended sediment and turbidity in the lower Missouri River below Gavins Point Dam (fig. 1) have occurred in response to extensive structural changes that have been imposed on the Missouri River and its watershed during the last two centuries. Efforts to shape the channel, remove snags and sawyers, dredge shallows, and stabilize banks for navigation began as early as 1838 (http:/7 www.lewis-clark.org/ri_mo-snagboats.htm, Chittenden, 1903). However, bank stabilization efforts were sporadic and scattered in comparison to large scale changes that occurred after 1929. In the early 1930s the numerous small channels were combined into a single-fixed channel with 4,745 stone and wood-pile dikes, 3,371 dike extensions, streambank protection works on concave banks, man-made cutoffs, the closing of chutes with dikes, the removal of snags, and dredging (Keown and others, 1981). The resulting navigation channel was 6-ft (feet) deep by $200-\mathrm{ft}$ wide and was expanded to 9 by $300 \mathrm{ft}$ in the 1950s and early 1960s. Construction of six dams was started in 1933 and their reservoirs were filled by 1967. Three of these reservoirs are among the five largest in the United States. Nearly one-third of the Missouri River is now submerged below these massive reservoirs. Since 1967, hydrologic changes have been relatively minor.

In the early 1970s, the U.S. Geological Survey (USGS) began the long-term, systematic collection of suspendedsediment and water-quality data that continues to the present (2006). Because changes in the channel configuration and

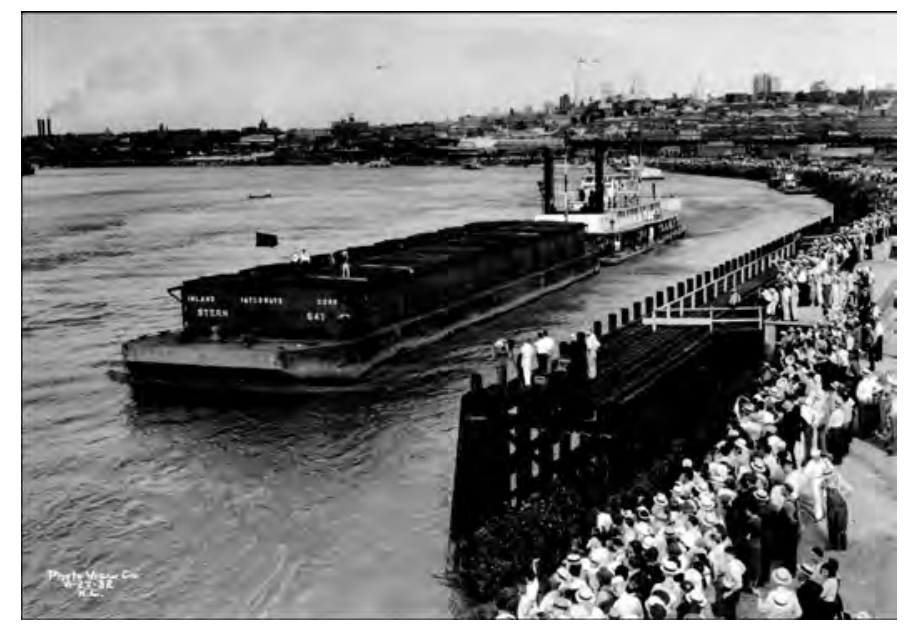

Ceremonies in Kansas City, Missouri, commemorating the opening of the 6-foot channel between Kansas City and St. Louis, Missouri, 1932. (Photograph used with permission from the Missouri Valley Special Collections, Kansas City Public Library, Kansas City, Missouri.)

hydrologic character of the river have been small compared to the changes before 1973, all samples collected after that time are referred to in this report as modern samples. These modern samples compose a large data set that are compared to samples collected before the pervasive hydrologic and channel-stabilizing changes that began in the early 1930s and to the qualitative and semiquantitative observations of the explorers in the early nineteenth century.

\section{Historical Measurements}

The largest change in the water quality of the lower Missouri River likely is the decrease of suspended sediment and turbidity, which are of importance to ecological communities, drinking-water utilities, and many other users of the modern river. Characterization of predevelopment suspended-sediment and turbidity concentrations is important to quantify the changes that have occurred. Unfortunately, the rare observations of suspended sediment and turbidity in the Missouri River before 1879 are semiquantitative to descriptive or anecdotal. 


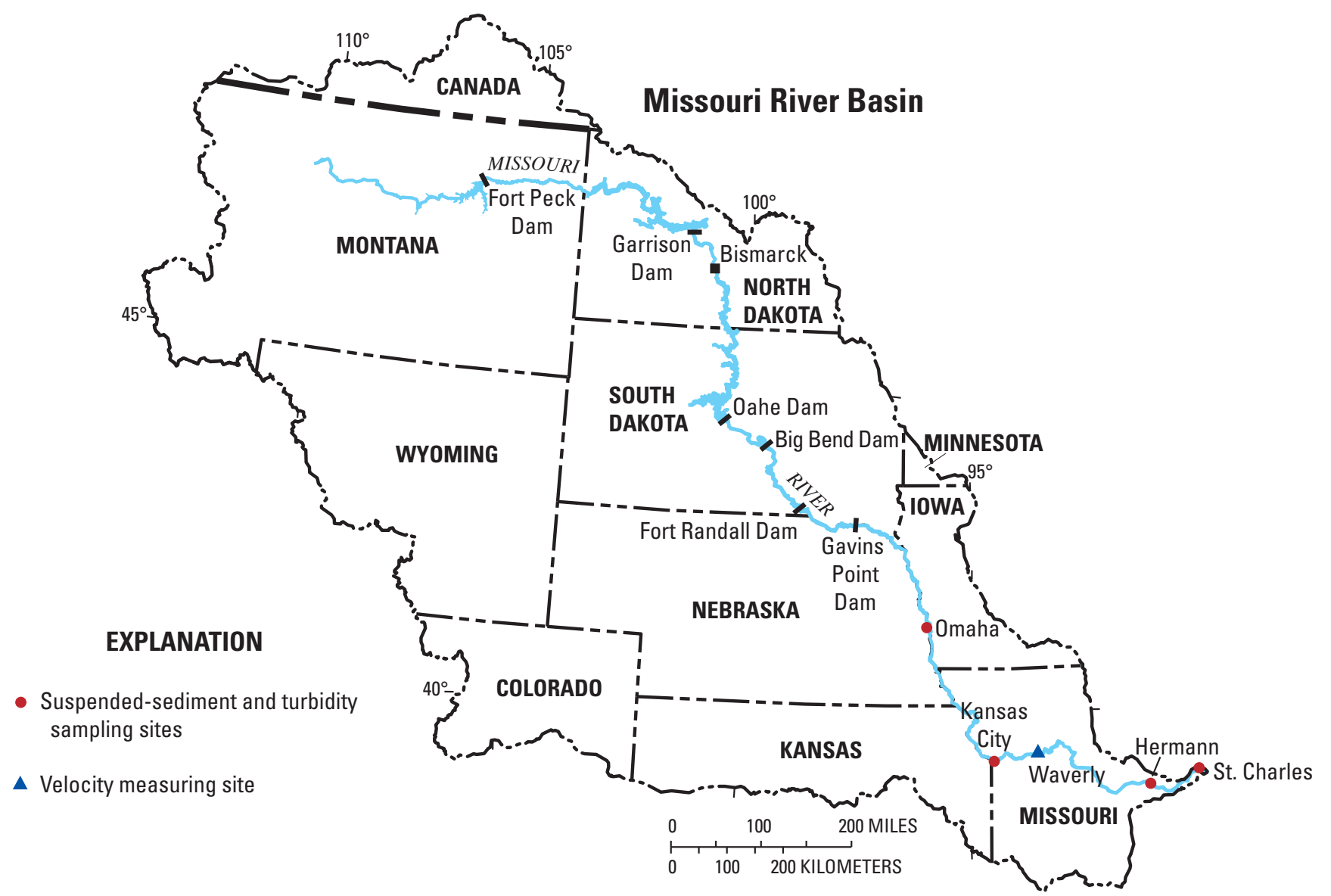

Figure 1. Missouri River Basin with location of historic and modern suspended-sediment, turbidity, and velocity sites on the Missouri River.

\section{Suspended Sediment}

Meriwether Lewis and William Clark made the first semiquantitative measurements of suspended sediment in 1804 in two ways:

"The water we Drink, or the Common water of the missourie [sic] at this time, contains half a Comn [sic] Wine Glass of ooze or mud to every pint" (Moulton, 1986) (Observed June 21, 1804, by William Clark at a high, but within-bank, stage near present-day Waverly, Missouri)

"Precipitate of one pint of Missouri water weight 80:65 grs (grains) [principally common Clay.]" [Reported by Meriwether Lewis (Moulton, 1986)]. (Collected in 1804 somewhere between present-day Bismarck, North Dakota, and the mouth of the Missouri River.)

Edward Harris in an expedition with John J. Audubon made the following observation (McDermott, 1951):

"No otters, beaver, muskrats, or even minks are found in about the turbid waters of this all-mighty stream, the water of which looks more like a hog puddle than anything else I can compare it to. About one-tenth of its bulk forms a despite (deposit) in half an hour." (Observed May 24, 1843, at a high, but within-bank, stage near present-day Gavins Point Dam)

Assuming the porosity of settled sediment was 40 percent, the specific gravity of suspended sediment was 2.6 (Chief of Engineers, 1935), and the size of William Clark's "wineglass" was 2 fl. oz (fluid ounces; Husted, 1957) the computed sediment concentrations for these observations are:

1. $98,000 \mathrm{mg} / \mathrm{L}$ (milligrams per liter; settleable sediment) $\left(92,000\right.$ parts per million) $\left[1 \frac{\mathrm{fl} . \mathrm{oz}}{\text { pint }} \times 30 \frac{\mathrm{cm}^{3}}{\mathrm{fl} . \mathrm{oz}} \times(1-0.40\right.$ porosity) $\left.\times 2,600 \frac{\mathrm{mg}}{\mathrm{cm}^{3}} \times 2.1 \frac{\text { pints }}{\text { liter }}\right]$,

2. $11,000 \mathrm{mg} / \mathrm{L}$ [Total solids. To estimate suspended-sediment concentration, approximately $400 \mathrm{mg} / \mathrm{L}$ dissolved solids is subtracted (Dole, 1909), which results in 10,600 $\mathrm{mg} / \mathrm{L}$ (10,500 parts per million), (865 grains/pint x 68 $\left.\left.\frac{\mathrm{mg}}{\text { grain }} \times 2.1 \frac{\text { pints }}{\text { liter }}\right)\right]$, and

3. $160,000 \mathrm{mg} / \mathrm{L}$ (Settleable sediment) $(150,000$ parts per million) $\left[\left(100 \mathrm{~cm}^{3}\right.\right.$ sediment/liter $) \mathrm{x}(1-0.40$ porosity $) \mathrm{x}$ $\left.2,600 \frac{\mathrm{mg}}{\mathrm{cm}^{3}}\right]$. 
William Teichmann collected and analyzed daily grab samples of total solids from the Missouri River 3 to $4 \mathrm{ft}$ below the water surface from a boat near St. Charles, Missouri, from January 24 through October 10, 1900, (Leighton, 1907). Because Teichmann's analyses were of total solids, the dissolved-solids concentration, which averaged approximately $400 \mathrm{ppm}$ (parts per million) before the reservoirs in 1907 (Dole, 1909), was subtracted from total-solids concentrations to estimate suspended-solids concentrations. Teichmann's median of 1,600 ppm was undoubtedly greater than the annual median because Teichmann did not collect samples from October 1, 1899, to January 23, 1900, when the Missouri River was low and correspondingly less turbid. Teichmann's largest suspended-solids concentration of 4,200 ppm is only 3 to 40 percent of the three semiquantitative measurements recorded by Lewis, Clark, and Audubon.

Grab samples were also collected daily from October 4, 1906, through October 14, 1907, (hereafter referred to as the 1907 water year), composited every 10 days, and analyzed for suspended sediment, total dissolved solids, turbidity, and several other constituents at five sites on the Missouri River as part of a nationwide survey of stream-water quality coordinated and published by Richard Dole of the USGS (Dole 1909; fig. 2). Samples usually were collected in 4-ounce bottles from bridges near the water surface. The median suspended-sediment concentration of the 10-day composite samples was 1,600 ppm at St. Charles, Missouri, and 1,550 ppm at Omaha, Nebraska. For the months corresponding to Teichmann's sampling period (January to October), Dole's 1907 median concentration was 2,320 ppm compared to the median of 10-day averages of Teichmann's daily data in 1900 of $1,800 \mathrm{ppm}$. The annual maximum concentration in 1907 was 6,330 ppm at St. Charles (fig. 2) compared to 3,000 ppm (again using 10-day averages) for 9 months during 1900. Suspended-sediment concentrations were greater in 1907 likely because the 1907 and 1900 water years had the second largest and fifteenth smallest annual discharges, respectively, in the 52-year period before substantial flow regulation between 1898 and 1950 (Stevens and Hardison, 1951). Despite these differences, Teichmann's and Dole's data are much more comparable than the two concentrations computed from the sediment-settling observations of William Clark and Edward Harris (measurements 1 and 3), which are more than 14 times the highest concentration measured by either Dole or Teichmann. This large difference casts some doubt on the accuracy of Clark and Harris's sediment-settling observations. However, both Clark's and Harris's observations were from instantaneous samples made near bankfull stages, whereas Dole's

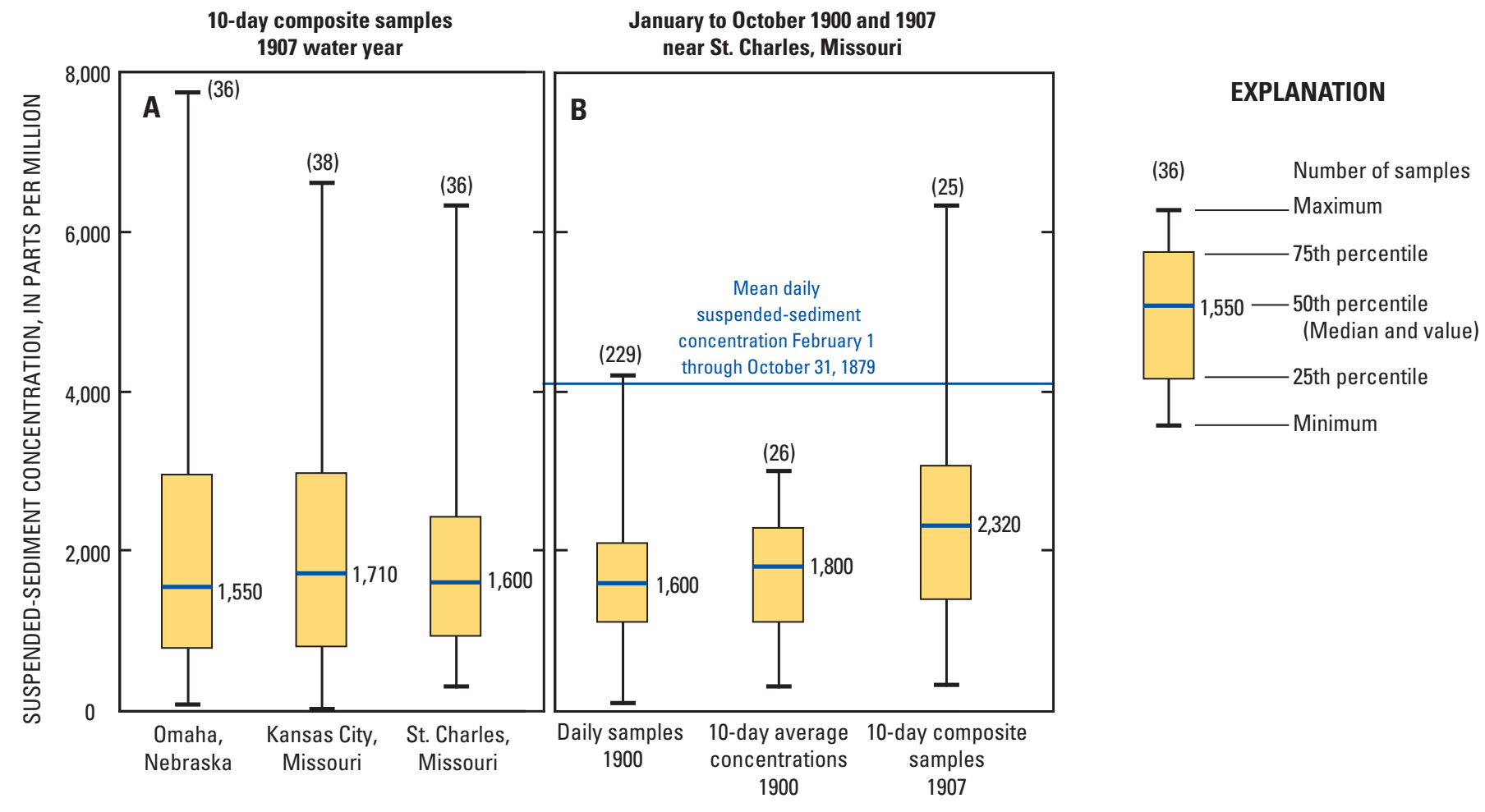

Figure 2. Summary of suspended-sediment concentrations before dams, large-scale bank stabilization, and watershed development (A) in 10-day composite samples collected at three locations on the lower Missouri River for water year 1907 (Dole, 1909) and (B) near St. Charles, Missouri, from February through October 1879 (median only), and January to October 1900 and 1907 [1907 data from Dole (1909); 1900 data modified from Leighton (1907) by subtracting 400 milligrams per liter dissolved solids from reported total-solids concentrations; 1879 data from Keown and others (1981)]. 
largest concentration is a 10-day composite sample. The instantaneous maximum during that 10-day period undoubtedly was much larger than $6,330 \mathrm{ppm}$.

The U.S. Army Corps of Engineers collected the first set of daily suspended-sediment samples on the Missouri River at St. Charles, Missouri, from February 1 to October 31, 1879, (Keown and others, 1981). Samples were collected at middepth and $1 \mathrm{ft}$ from the bottom at eight points equally distributed across the river. A physical description of the sampling device was not included in the documentation. The average daily discharge during this period was $83,000 \mathrm{ft}^{3} / \mathrm{s}$ (cubic feet per second), which is 5 percent less than the modern average annual discharge at Hermann, Missouri (Hauck and Nagel, 2002), just upstream. The average suspended-sediment concentration during this 9-month period was $4,100 \mathrm{mg} / \mathrm{L}$. Despite the less than average discharge, this mean concentration is near the maximum concentration of daily samples collected by Teichman for nearly the same period in 1900 (fig. 2), but substantially less than concentrations computed from the observations of the early explorers.

Another set of suspended-sediment data were collected at eight Missouri River sites by the U.S. Army Corps of Engineers (Chief of Engineers, 1935) from May 8, 1929, to July 22,1932 , before reservoir construction and just preceding and during the initial construction of the first 6 - $\mathrm{ft}$ deep by $200-\mathrm{ft}$ wide channel. At most sites sample concentrations were plot- ted against daily discharge to develop a sediment-discharge curve that was used to estimate daily and monthly suspendedsediment concentrations. This method was enhanced at most sites with the collection of hundreds of samples during 3 years. Also, samples were collected at equal-width increments across the stream and at up to five different depths to develop methods for collection of representative samples. Consequently, these data, while not all preceding the initial construction of the 6 by $200-\mathrm{ft}$ channel, likely are more representative and reliable than the grab samples collected by Teichmann and Dole. Despite the monthly time step (daily maximums are usually greater than 10-day or monthly-average maximums) and the low discharges between July 1, 1929, and June 30, 1930 , the annual maximum of monthly concentrations near St. Charles $(6,650 \mathrm{ppm})$ is larger than the daily maximum reported by Teichmann for 1900 (4,200 ppm) and Dole's 10day composites in 1907 (6,330 ppm; figs. 2 and 3). However, the average suspended-sediment concentration in $1879(4,100$ $\mathrm{ppm}$ ) would fall well within the upper quartile of monthly concentrations at St. Charles, Missouri, from 1929 to 1932. The maximum instantaneous concentration in the 1929 to 1932 data was $12,440 \mathrm{ppm}$ measured in a sample collected on June 4, 1929, at Kansas City, Missouri, at a discharge of 224,000 $\mathrm{ft}^{3} / \mathrm{s}$ (Chief of Engineers, 1935) and a stage about $2 \mathrm{ft}$ over bankfull. This high concentration provides some credibility to Meriwether Lewis' evaporative measurement (measurement 2)

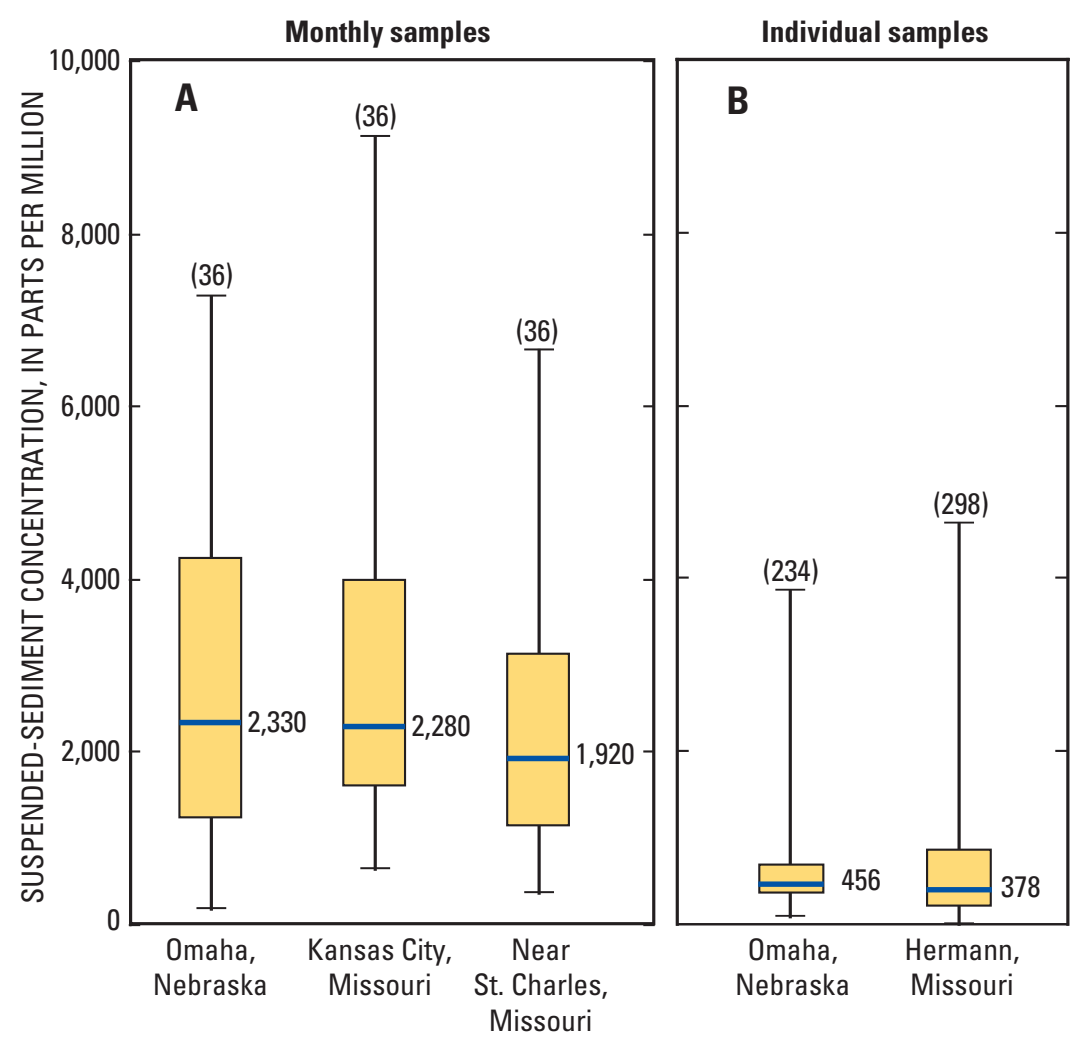

\section{EXPLANATION}

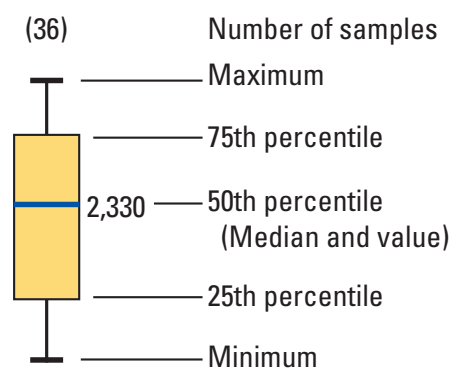

Figure 3. Summary of monthly suspended-sediment concentrations in the Missouri River from (A) July 1, 1929, through June 30, 1932 (Chief of Engineers, 1935) and (B) individual samples collected from 1973 through 2002 (U.S. Geological Survey at http://nwis.waterdata. usgs.gov/mo/nwis/qwdata, accessed on July 1, 2005). 
of $10,600 \mathrm{mg} / \mathrm{L}$. Conversely, the 1929 to 1932 data cast more doubt on the settleable-sediment observations of Clark and Harris. The median of monthly concentrations in the 1929 to 1932 data, collected 9-river miles upstream from St. Charles, Missouri, was 1,920 ppm (fig. 3), which is more than, but comparable to, Teichmann's January to October 1900 median (1,600 ppm) of daily samples and Dole's 1907 median (also 1,600 ppm; fig. 2) of 10-day composite samples. The lower concentrations reported by Teichmann and Dole may partly be caused by under representation of suspended sediment in grab samples collected near the water surface.

\section{Turbidity}

The large suspended-sediment concentrations in the uncontrolled river caused it to be so turbid that the water usually was opaque:

\section{"One of the difficulties, the navigator never ceases to contend with, from the entrance of the Missouri to this place (near present-day Bismarck, North Dakota)... [is] the turbed [sic] quality of the water, which renders it impracticable to discover any obstruction even to the debth [sic] of a single inch." (Meriwether Lewis 1804, in Jackson, 1978).}

Large concentrations of sediment in the lower Missouri River before major river modifications in the 1930s also are reflected in the large values of turbidity reported by Dole
(1909; fig. 4). The longitudinal variability of turbidity was small in 1907 as the median, $25^{\text {th }}$, and $75^{\text {th }}$ percentile values for Kansas City, Kansas, and St. Charles, Missouri, are nearly identical (fig. 4). At Omaha, Nebraska, located above the Platte River and with lower velocities [William Clark (in Moulton, 1986)], the median turbidity was only 13 to 18 percent less than at the other two sites. Turbidity was well correlated with suspended-sediment concentrations $\left(\mathrm{r}^{2}=0.91\right.$; fig. 5) at Kansas City, Kansas, and other sites.

\section{Comparison with Modern Measurements}

Historically, suspended-sediment concentrations were reported in parts per million, whereas milligrams per liter are used for modern samples. However, the difference in these units is less than the precision of the laboratory analyses at the concentrations reported, except for the three large concentrations observed by William Clark, Meriwether Lewis, and Edward Harris (measurements 1 to 3), that require corrections for sample density. Therefore, except for these three values, comparisons between historical concentrations in parts per million and modern concentrations in milligrams per liter are reasonable. Comparing post-1972 with pre-1932 data shows how severely suspended-sediment concentrations and turbidity have decreased in the lower Missouri River. The 1973 through
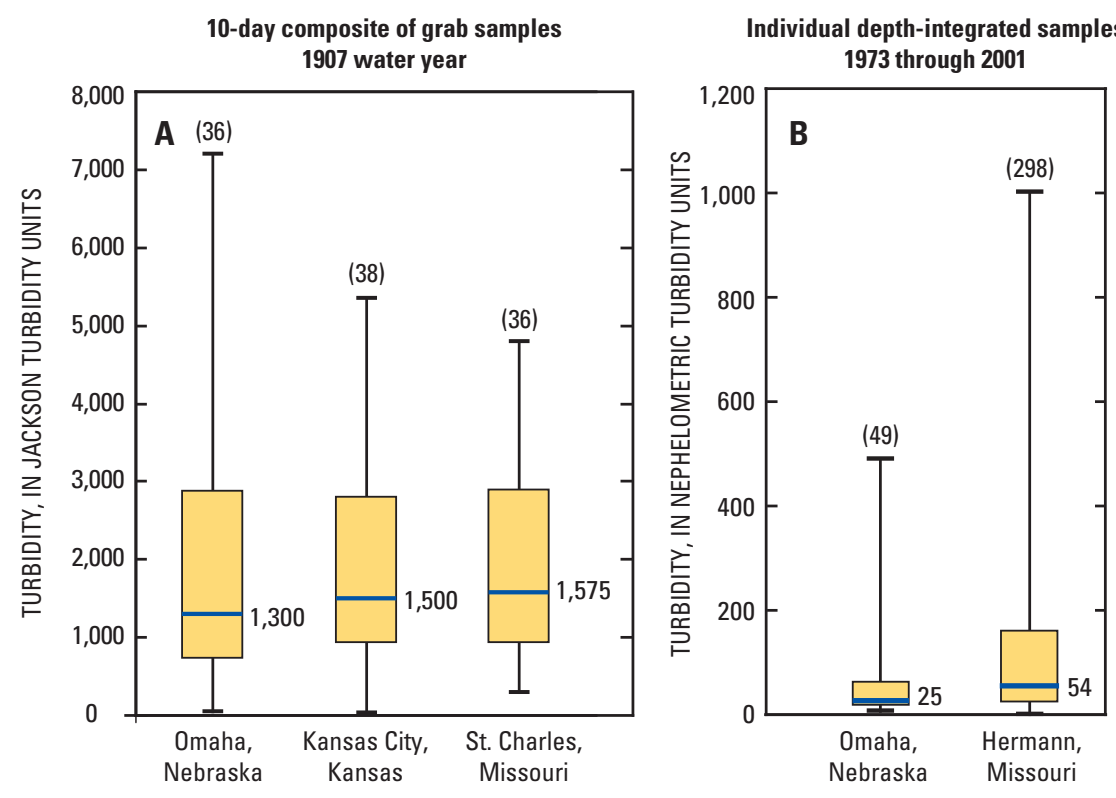

Figure 4. (A) Turbidity in 10-day composite of grab samples collected in the 1907 water year (Dole, 1909) and (B) Turbidity in depth-integrated samples collected from 1973 through 2001 (U.S. Geological Survey at http://nwis. waterdata.usgs.gov/mo/nwis/qwdata, accessed July 1, 2005). NOTE: Jackson Turbidity Units and Nephelometric Turbidity Units are not necessarily equivalent at values greater than 40 because of the use of different methods of measurement (American Public Health Association, American Water Works Association, and Water Environment Federation, 2005). 


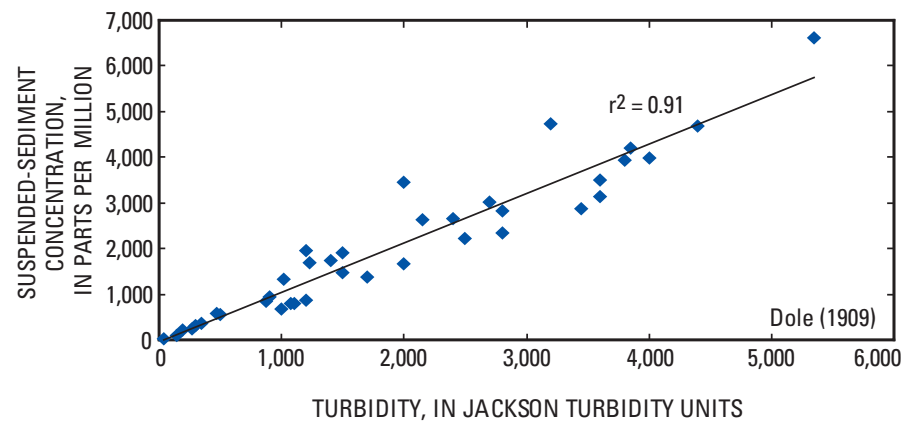

Figure 5. Turbidity with suspended-sediment concentration at Kansas City, Kansas, in the 1907 water year.

2002 median suspended-sediment concentration of 234 instantaneous samples collected at Omaha, Nebraska, is 456 $\mathrm{mg} / \mathrm{L}$, which is less than 30 percent of the median suspendedsediment concentration of 10-day composite samples collected in 1907 by Dole (1909; figs. 2 and 3). The modern median is also less than 20 percent of the median of monthly suspendedsediment concentrations at the same city, from July 1, 1929, through June 30, 1932, (fig. 3). The median suspended-sediment concentration at Hermann, Missouri, from 1973 through 2002 is $378 \mathrm{mg} / \mathrm{L}$, which is less than 10 percent of the average concentration in 1879 , less than 25 percent of the median concentration in 1907 (fig. 2), and is less than 20 percent of the 1929 to 1932 median concentration near St. Charles, Missouri.

Comparisons of modern data with the three nonsystematic measurements of the early explorers are even more remarkable. Clark's settleable-sediment measurement near Kansas City, Missouri, is 210 to 270 times the modern median concentrations at Omaha, Nebraska, and Hermann, Missouri, and more than 21 times the maximum concentration measured at these two sites from 1973 through 2002. Although, Meriwether Lewis' suspended-sediment measurement of 10,600 $\mathrm{mg} / \mathrm{L}$ is much less than Clark's and Harris's observations, it is still more than $6,000 \mathrm{mg} / \mathrm{L}$ greater than the maximum concentration measured at Omaha, Nebraska, since 1973.

Unfortunately, Dole's measurements of turbidity in 1907 used a different method and different units (Jackson turbidity units, JTU) than modern measurements (nephelometric turbidity units). Consequently, the measurements are not necessarily equivalent at values greater than about 40 JTU (American Public Health Association, American Water Works Association, and Water Environment Federation, 2005). Nevertheless, the difference between the medians of these two data sets is greater than an order of magnitude (fig. 4), which indicates an exceptional increase in water clarity.

The effects of reservoirs on turbidity also are evident in analyses of samples (using a consistent method of analysis) collected at the Kansas City, Kansas, water-treatment plant from 1918 to 1954 (U.S. Department of Health, Education, and Welfare-Public Health Service, 1955; fig. 6). Fort Peck Dam closed in 1937, Fort Randall Dam in 1952, and Garrison Dam in 1953. Almost immediately turbidity decreased by more than 50 percent. Given the strong relation between turbidity and suspended sediment, the reservoirs likely exacted a similar effect on suspended sediment. Later dams and further bank stabilization likely decreased turbidity even more. These data indicate reservoirs and bank stabilization of the 1950s have decreased turbidity more than the bank stabilization of the early 1930s (fig. 4).

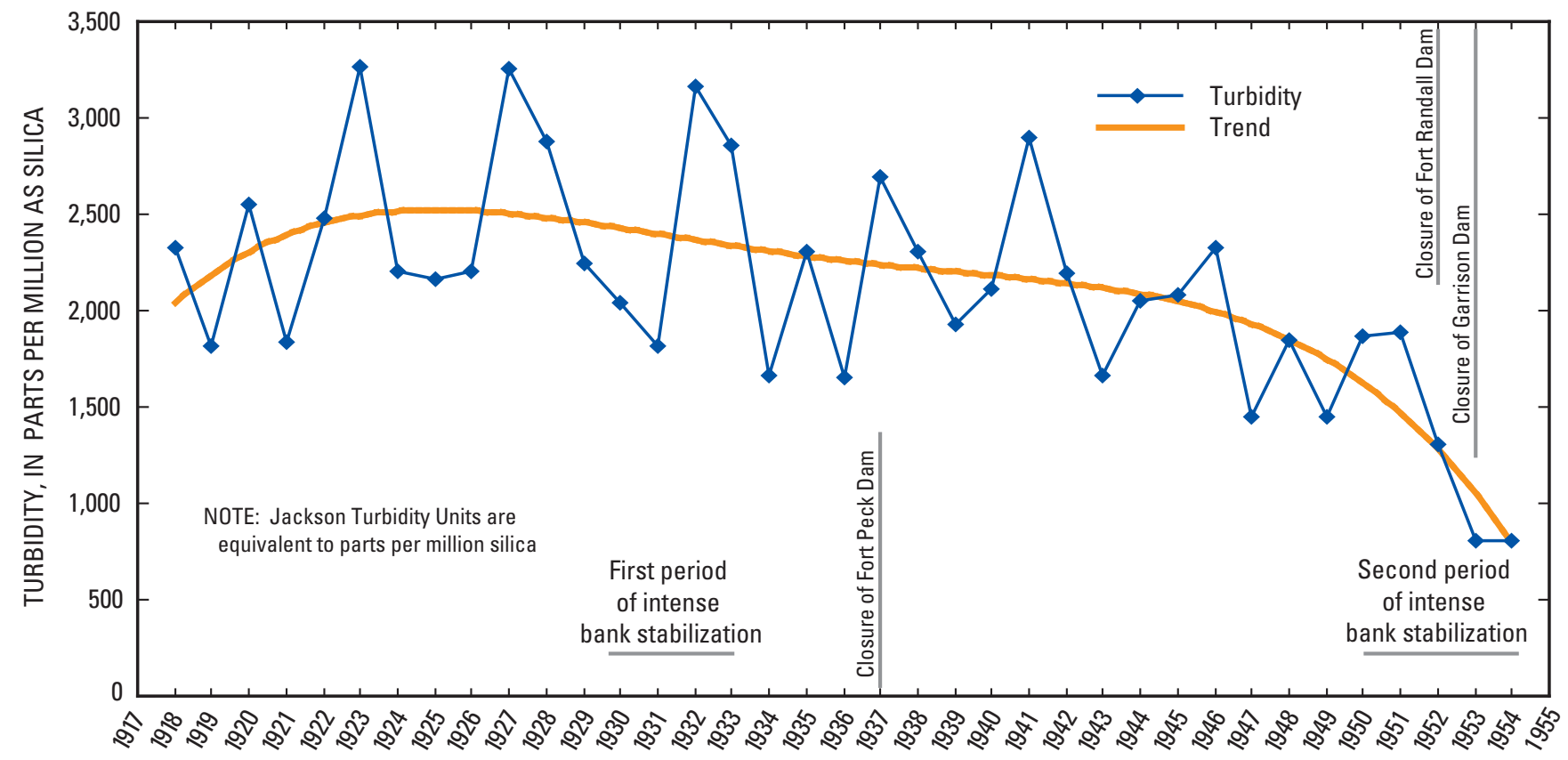

Figure 6. Average annual turbidity at the Kansas City, Kansas, Water Plant, 1918 through 1954 (U.S. Department of Health, Education, and Welfare-Public Health Service, 1955) with best-fit fourth-order polynomial trend line. 


\section{Comparison of Suspended-Sediment Concentrations from Sources Cited in this Report}

\begin{tabular}{|c|c|}
\hline $\begin{array}{l}\text { Milligrams } \\
\text { per liter or } \\
\text { parts per } \\
\text { million }\end{array}$ & $=2$ \\
\hline 160,000 & $\begin{array}{l}\text { Computed concentration of a single observation by Edwin James on May 24, 1843, near present-day Gavins } \\
\text { Point Dam. }\end{array}$ \\
\hline 98,000 & $\begin{array}{l}\text { Computed concentration of a single sample collected by William Clark on June 21, 1804, near present-day } \\
\text { Kansas City, Missouri. }\end{array}$ \\
\hline 10,600 & $\begin{array}{l}\text { Computed concentration of a single sample collected by Meriwether Lewis in } 1804 \text { between Bismarck, } \\
\text { North Dakota, and the mouth of the Missouri River. }\end{array}$ \\
\hline 4,100 & $\begin{array}{l}\text { Mean concentration of daily samples collected by U.S. Army Corps of Engineers at St. Charles, Missouri, } \\
\text { from February } 1 \text { to October 31, 1879. }\end{array}$ \\
\hline $1,920-2,330$ & $\begin{array}{l}\text { Median concentrations of monthly means of daily samples collected by the U.S. Army Corps of Engineers at } \\
\text { Omaha, Nebraska; Kansas City, Missouri; and St. Charles, Missouri, from July 1, 1929, through June 30, } 1932 \text {. }\end{array}$ \\
\hline $1,550-1,710$ & $\begin{array}{l}\text { Median concentrations of 10-day composite grab samples collected by Richard Dole of the U.S. Geological } \\
\text { Survey at Omaha, Nebraska; Kansas City, Kansas; and St. Charles, Missouri, from October 4, 1906, to } \\
\text { October 14, } 1907 .\end{array}$ \\
\hline 1,600 & $\begin{array}{l}\text { Median concentration of daily grab samples collected by William Teichmann near St. Charles, Missouri, } \\
\text { from January } 24 \text { through October 10, } 1900 .\end{array}$ \\
\hline $456-378$ & $\begin{array}{l}\text { Median concentration of individual samples collected by the U.S. Geological Survey from October 1, 1972, } \\
\text { through September 30, 2002, at Omaha, Nebraska, and Hermann, Missouri. }\end{array}$ \\
\hline
\end{tabular}

\section{River Velocities}

The large historical decrease in suspended sediment and turbidity seems inconsistent with the common assumption that the Missouri River flows much faster than it did before bank stabilization. However, comparison of modern velocity measurements with available measurements made before bank stabilization indicate that while mean velocities are similar, maximum velocities in the lower Missouri River were substantially larger before bank stabilization than maximum velocities measured today. For example, the 25 predevelopment discharge measurements made at Waverly, Missouri, (fig. 1) between October 1928 and May 1930 have mean water velocities that are only 0.2 to $0.8 \mathrm{ft} / \mathrm{s}$ (foot per second) slower than mean velocities measured at this same site between October 1993 through September 2002 (fig. 7). However, maximum water velocities before bank stabilization were actually 1.1 to $1.6 \mathrm{ft} / \mathrm{s}$ faster than modern maximum velocities (fig. 8). The maximum velocity measured at this same site with a logline by William Clark on June 17, 1804, was $12.5 \mathrm{ft} / \mathrm{s}$ (Moulton, 1986), which is close to the maximum high-water velocity of $11.9 \mathrm{ft} / \mathrm{s}$ measured in 1929 before bank stabilization. These data refute the hypothesis that the Missouri River was substantially slower before bank stabilization and help explain how the river could suspend such large quantities of sediment and sustain such high turbidity values (fig. 7). Slightly lower mean velocities and substantially higher maximum velocities before bank stabilization indicate the range and spatial variation of water velocity was likely greater before bank stabilization.

\section{Conclusions and Implications}

Median suspended-sediment concentrations in the lower Missouri River appear to have decreased by at least 70 to 80 percent from predevelopment conditions, although two semiquantitative sediment-settling observations made by William Clark and Edward Harris indicate even larger reductions in maximum concentrations. Regardless of the amount of reliability that might be ascribed to the Clark and Harris measurements, the decrease in suspended-sediment concentrations and increase in water clarity of the Missouri River is remarkable. Most of this decrease occurred after the closure of dams and massive bank stabilization activities that occured in the 1950s and 1960s. The ecological change that may have resulted from the decrease in suspended-sediment and turbidity has not been documented. However, numerous ecological changes can be postulated from fundamental principles of aquatic ecology (Horne and Goldman, 1994). For example, the greater range in velocities likely resulted in a greater range in turbidity and a greater variety of fish habitat. Also, increased water clarity may permit algal photosynthesis at low river stages providing a new energy source for the food chain and a niche for nonnative planktivorus fish. Increased water clarity should benefit sight-feeding fish, perhaps at the expense of native fish such as catfish, drum, and the endangered pallid sturgeon, that need little light to find food. Thus, the top end of the food chain also may be altered with a potential trophic cascade that could substantially alter the food chain and populations of many species. Conversely, drinking-water suppliers and other users 


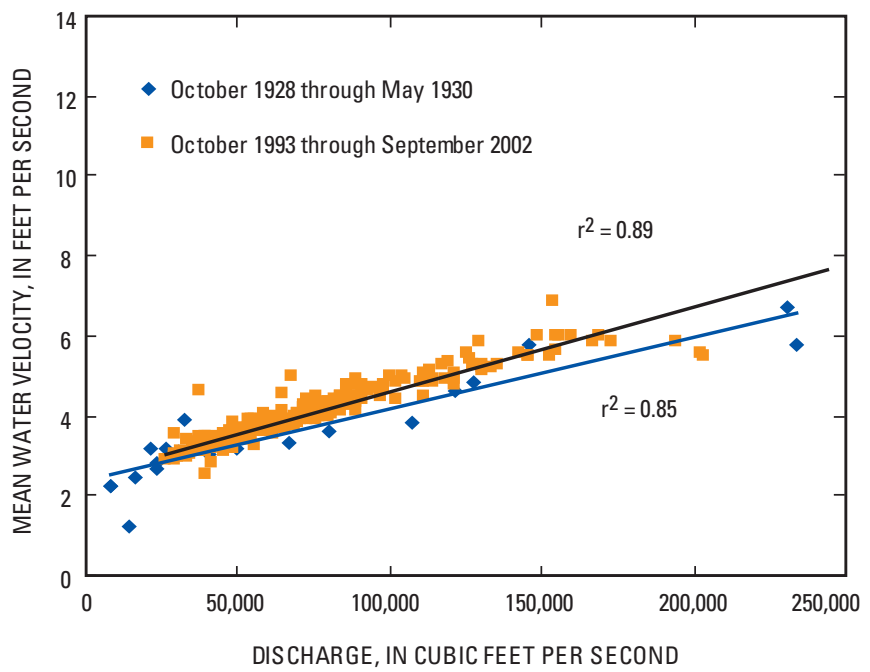

Figure 7. Relation between mean water velocity and discharge in the Missouri River at Waverly, Missouri, as recorded in U.S. Geological Survey discharge measurement notes.

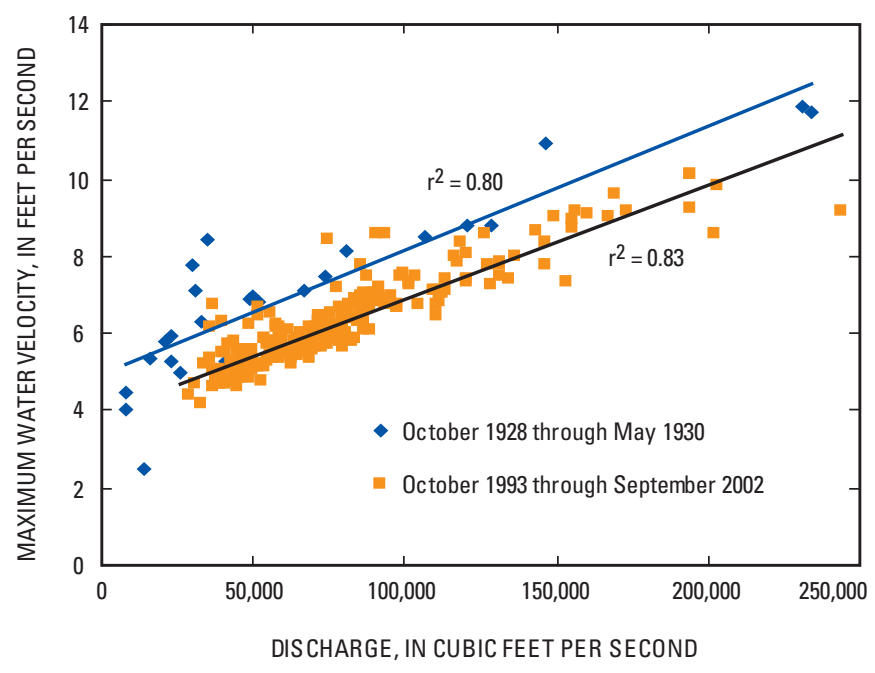

Figure 8. Relation between maximum water velocity and discharge in the Missouri River at Waverly, Missouri, as recorded in U.S. Geological Survey discharge measurement notes.

who must remove river sediments benefit from the decrease in suspended material.

\section{References}

American Public Health Association, American Water Works Association, and Water Environment Federation, 2005, Standard methods for the examination of water and wastewater, (21 ${ }^{\text {st }}$ ed. $), 900 \mathrm{p}$.
Chief of Engineers, 1935, Letter from Secretary of War, $73^{\text {rd }}$ Congress, $2^{\text {nd }}$ session, House Document No. 238: United States Government Printing Office, Washington, D.C., $1,245 \mathrm{p}$.

Chittenden, H., 1903, History of early steamboat navigation on the Missouri River: New York, Francis P. Harper, v. 2, 420 p.

Dole, R.B., 1909, The quality of surface waters of the United States: U.S. Geological Survey Water-Supply Paper 236, $123 \mathrm{p}$.

Hauck, H.S., and Nagel, C.D., 2002, Water resources dataMissouri, water year 2002: U.S. Geological Survey Water Data Report MO-02-1, 543 p.

Horne, A.J., and Goldman, C.R., 1994, Limnology, (2 ${ }^{\text {nd }}$ ed): McGraw-Hill, 576 p.

Husted, Mrs. W., ed., 1957, Virginia Cookery Past and Present: The Woman's Auxiliary of Olivet Episcopal Church Franconia, Virginia, p. 431.

Innis, B., 1985, Sagas of the Smoky-Water: Williston, North Dakota, Centennial Press, 432 p.

Jackson, D., 1978, Letters of the Lewis and Clark Expedition with Related Documents, 1783-1854 (2nd ed.): Urbana, University of Illinois Press, p. 222-25.

Keown, M.P., Dardeau, E.A., and Causey, E.M., 1981, Characterization of the suspended-sediment regime and bed-material gradation of the Mississippi River Basin: U.S. Army Corps of Engineers Waterways Experiment Station Potamology Program Report 1, v. 1, 494 p.

Leighton, M.O., 1907, Pollution of Illinois and Mississippi Rivers by Chicago Sewage: U.S. Geological Survey WaterSupply and Irrigation Paper No. 194, Series L, Quality of Water 20, 369 p.

McDermott, J.F., 1951, Up the Wide Missouri with Audubon: the Journal of Edward Harris: University of Oklahoma Press, $222 \mathrm{p}$.

Moulton, G., ed., 1986, The Journals of the Lewis \& Clark Expedition (v. 2): University of Nebraska Press, Lincoln, Nebraska, 612 p.

Stevens, G.C., and Hardison, C.H., 1951, Monthly and annual discharge of Missouri River between Fort Benton, Montana And Hermann, Missouri, and principle tributaries: U.S: Geological Survey Circular 108, 37 p.

U.S. Department of Health, Education, and Welfare-Public Health Service, 1955, Central Missouri River Water Quality Investigation, $79 \mathrm{p}$. 


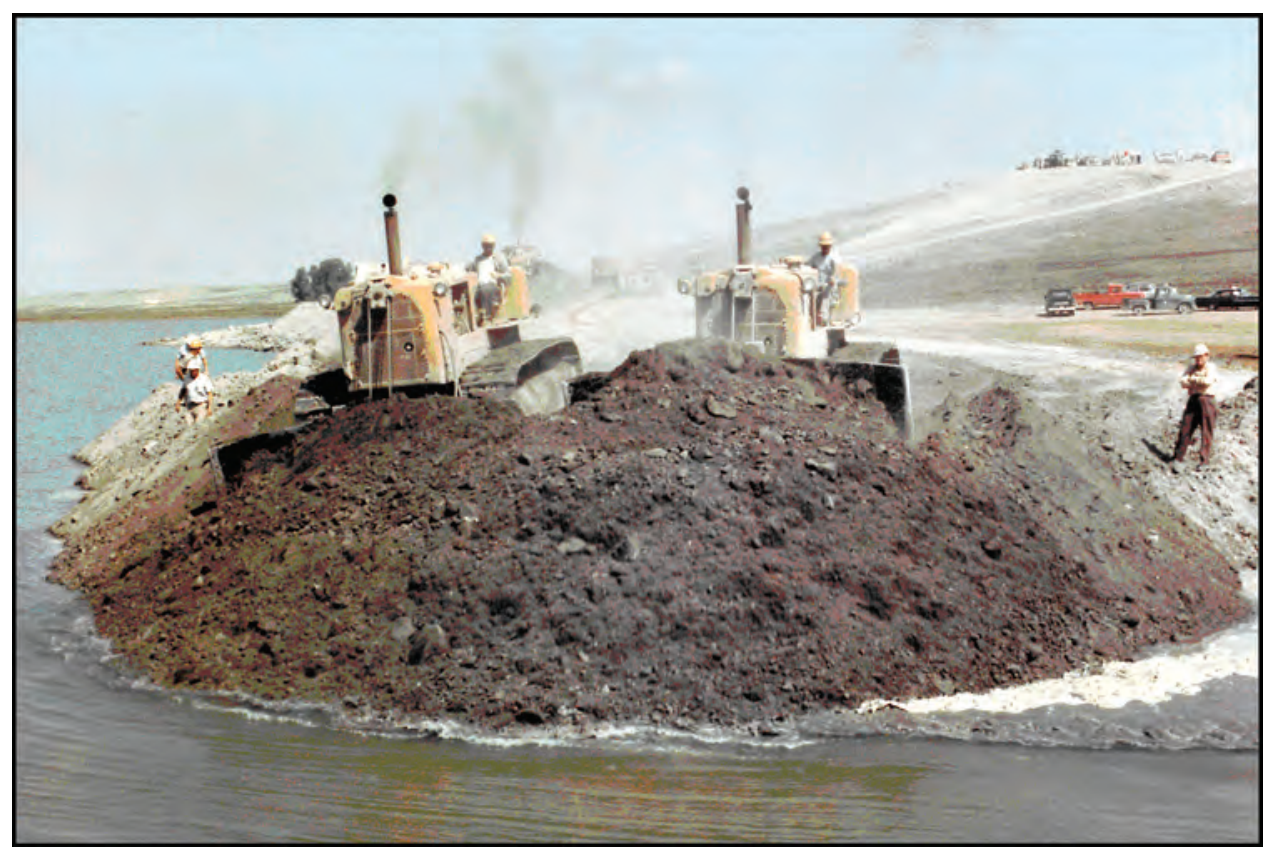

Closure of Big Bend Dam in 1963. Construction of six large reservoirs on the upper Missouri River have greatly decreased the amount of suspended sediment and turbidity in the lower river. (Photograph courtesy of the U.S. Army Corps of Engineers.) 

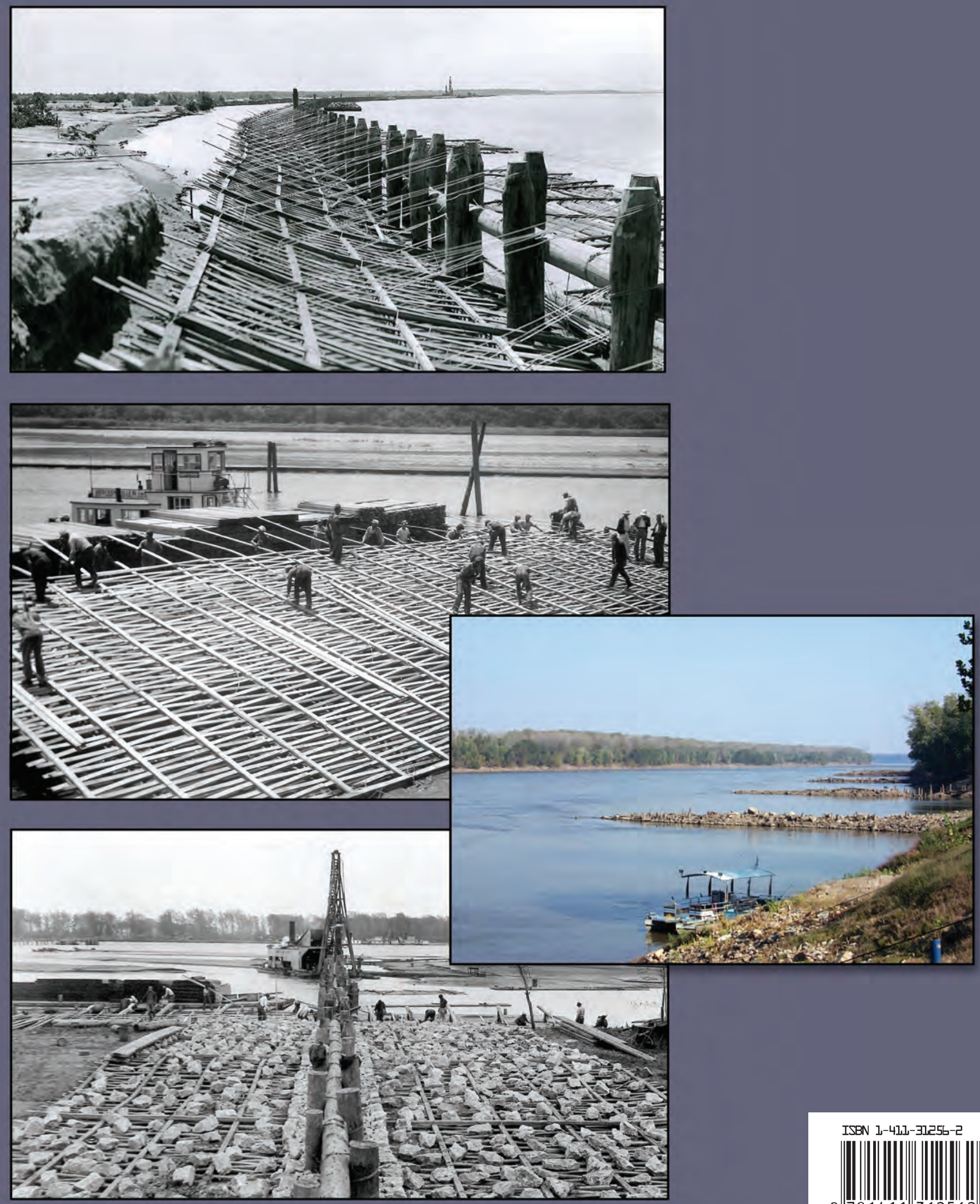

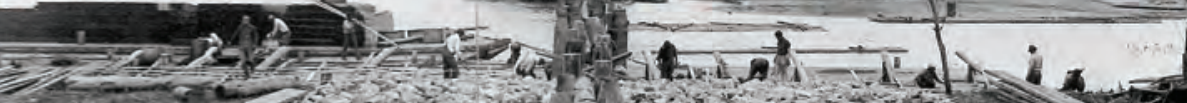

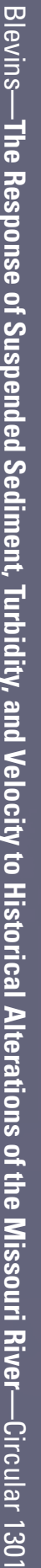

